24 Fifty Years Work Without Wages, 7, 9, 131.

25 Unpublished diary, Angeli-Dennis Papers.

\title{
GRACE ELLERY CHANNING AND THE WHITMAN CALENDAR
}

In documenting Whitman's brief time of celebrity in 1887-1888 and the commercialization of his name that accompanied it (e.g., the Walt Whitman cigar), David Reynolds in Walt Whitman's America makes reference to Grace Ellery Channing, "a Pasadena woman," who, he says, requested permission "to publish a Walt Whitman calendar, with illustrated excerpts from his poems." Not certain as to whether or not the calendar ever appeared, Reynolds moves on to yet another example, the Whitman tree dedicated by public school students in Bath, Maine in 1889. Grace Channing's connections to the world of nineteenth-century literature and to Whitman are deserving of greater acknowledgement than this single passing, and not even footnoted, reference in Reynolds's book.

Grace Ellery Channing (1862-1937) was the daughter of William F. Channing, medical doctor, inventor, and son of the highly esteemed Unitarian clergyman, William Ellery Channing, whose writings greatly influenced the young Ralph Waldo Emerson. Her mother was Mary Tarr Channing, sister of Ellen Tarr who became the wife of Whitman's famous champion, William Douglas O'Connor. Grace's numerous New England relatives included cousin Thomas Wentworth Higginson. As a young girl growing up in Providence, Rhode Island, Grace Channing became great friends with Charlotte Perkins Gilman, whose family was also among New England's most illustrious and included her grandfather, Lyman Beecher, and her great aunt Harriet Beecher Stowe.

Fostered by their mutual background and a shared longing for literary careers, the bonds between Grace and Charlotte grew strong, and in 1885 when Charlotte found herself, soon after the birth of her daughter Katherine, desperately unhappy in her marriage to the artist Walter Stetson, Grace's parents invited her to visit them in their Pasadena, California, home. The Channings had moved to California on the advice of Grace's doctor when her persistent respiratory problems were diagnosed as tuberculosis, and they were pleased to provide help to their daughter's friend and companionship to Grace in her illness. Without the distractions of husband and baby, Charlotte was able to paint a bit, and she and Grace wrote a play. In 1887 when Charlotte, having endured the S. Weir Mitchell treatment of her nervous disorder so dramatically portrayed in her short story "The Yellow Wallpaper," reached a separation agreement with her husband, the Channings rented a small house for her and her daughter very near their Pasadena home. Grace and Charlotte resumed their joint writing ventures, and, when Charlotte's husband came to visit, her parents encouraged him to remain by making a room in their home into a studio where he could work.

Under this arrangement, and with the Channings-especially Grace-actively promoting Walter Stetson's career, Charlotte's emotional life improved 
and her career flourished. Increasingly engaged in the cause of female suffrage, the nascent labor movement, and later in Edward Bellamy's Nationalist clubs, she had little time for her husband and daughter. Grace became more and more important in their lives. In 1894 Charlotte succeeded in obtaining a California divorce, and before the year was out Grace Channing married Walter Stetson. After a period of trying to maintain herself, her child, an ailing mother, and a succession of female lovers, Charlotte made the then unprecedented move of relinquishing Katherine to her father. Grace then became mother to Charlotte's child, freeing Charlotte to become the successful orator and author she proved to be.

In the winter of 1887, when Charlotte reached the lowest depths of depression, it was Grace Channing who did all she could to improve her spirits with a steady flow of letters filled with plans for work. ${ }^{2}$ Grace had entered upon a great project, editing the journals of her grandfather William Ellery Channing, and also had hit upon an idea that she hoped would further Walter Stetson's career, an illustrated calendar featuring excerpts from Leaves of Grass. The genesis of the idea was no doubt the visit of her uncle, William Douglas O'Connor, who had all but dragged his ailing body to her parents' Pasadena home in February of that year. ${ }^{3} \mathrm{O}^{\prime}$ Connor and the Channings had shared happy times when, as a child, Grace had accompanied her parents on visits to the Washington, D.C., home of her aunt Ellen and husband where they listened in awe to the wide-ranging and highly volatile conversations of her uncle's circle of friends. But, as Grace wrote in her unpublished memoir, all the others "were frankly subsidiary to the two friends, the two brilliant figures of

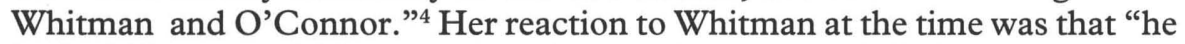
looked like an amiable lion," but that he had none of O'Connor's charm: "One sat on his knee and allowed him to stroke one's curls, but always with an eye to wriggling away." ${ }^{5}$ The Channings were not present when O'Connor and Whitman had their great falling out, sometime in 1872, but her unpublished memoir contains the account of its effect on her parents and their understanding of its cause. ${ }^{6}$

In 1883, a year after his reconciliation with Whitman, William O'Connor left with his niece a gift for her friend Charlotte, a copy of Leaves of Grass. Charlotte wrote in her diary that she was "obliged" to decline the gift "as I had promised Walter I would not read it." 7 Walter was at that time engaged to Charlotte and professed a fear that his future wife would dread the marriage bed if she read Whitman: "I did not want her to think all men such animals as Whitman described them," he noted in his diary. ${ }^{8}$ Two months after Charlotte had obeyed his wishes and declined to read Leaves, Stetson found himself, while at his morning bath, measuring his own naked body against the standards of physicality expressed in Whitman's poems. Obviously worried that he may have been wrong in his prohibition, and only vaguely conscious of his underlying fear of not measuring up to expectations that the poems might arouse in his future wife, he argues with himself in his diary and gives us a rare insight into contemporary male reactions to Whitman's blatant sensuality:

I wanted her to find love and the sexual relations something so holy and lovely that it goes into some hidden place to enjoy its holiness rather than stands in the market 
places and cries up the odor of its perspiration, the action of its phallus, the hairiness of sweating breasts - and all the Whitman delicacies. . . . But, said I to myself, surely she should have a chance. She is pure and honest. Let her read it. . . . If Whitman's tales of harlots and dithyrambic explanations of generation can make her believe my love to be weak and ill-so be it. ${ }^{9}$

Stetson had not changed his mind about Whitman when he responded to Grace Channing's letter suggesting the calendar. Although to her he claimed to "think more highly, and probably more truly" of the poet at each rereading of his work, he confided to his diary, "Whitman suggests a satyr to me-a very knowing one too." ${ }^{10}$ As to the calendar design, he proposed individual pages $3 \frac{1}{2}$ " $\times 4$ " "and a photogravure in some warm tint of the head of the poet, surrounded by a sort of wreath of lilac leaves and pine (with cones and needles of course)." 11 Continuing, he described a rather macabre, Hamlet-like decoration: "Then I thought that at the sides I could faintly - I mean delicatelyindicate the evolution out of mortality to life that is so strong a feature in many of the poems, by a half-buried inoffensive skull, out of surface of whichmerges the 'leaves of grass,' with their seeds, perhaps." Anticipating that this might seem to Grace "rather ghastly," he claimed not to know of any better way to express the death-into-life cycle "than by the accepted emblem of death out of which grows grass that so pleases [Whitman]."12

The idea of the calendar did not please Whitman. In August of 1888 he told Horace Traubel:

I not only don't enthuse-I do not even approve. Leaves of Grass does not lend itself to piecemeal quotation: can only find its reflection in ensemble, ensemble: cannot be rendered by any selection of pretty lines, strange allusions, passages from here and there: it belongs to bulk, mass, unity: must be seen with reference to its eligibility to express world-meanings rather than literary prettinesses. ${ }^{13}$

Yes, he admitted, "Grace Channing is a bright, good girl, too, and might be trusted to do what could be done in that sort of work and with Leaves of Grass. But my first impression was a bad one and I have not moved from it. I shall not interfere . . . but I shall have my friends know that I don't endorse calendars or any other such miniaturing from Leaves of Grass."14

When there was no response to the proposal for over a year, William O'Connor attempted to prod the poet by sending a copy of Stetson's letter (quoted above) to Grace. Acknowledging to Traubel Stetson's artistic abilities, Whitman again dismissed the idea with the comment: "But I am always asking myself about all that calendar business - what's the use? I can't see that it leads to anything worth while: but I'm not responsible for it: I wash my hands of it." 15 The following day, regretful perhaps at his previous outburst, Whitman said of the calendar suggestion that it was "noteworthy." But it was never produced. Whitman did not respond to Grace or to Walter, and so O'Connor excused the poet to his niece, claiming illness made it difficult for him to make such decisions. ${ }^{16}$ It is clear that even in old age and despite his somewhat unseemly grasping after celebrity, Whitman never lost his vision of the organic unity of Leaves and its essential harmony. 
Grace Ellery Channing edited her grandfather's memoirs and continued to pursue a writing career, eventually publishing many essays, short stories and poems, and reporting from Europe as a war correspondent in World War I. In 1899 (the same year Gilman's “The Yellow Wallpaper" appeared), she published a collection of poems titled Sea-Drift, named after a section of Leaves of Grass. The poems were largely the product of a visit to Italy that extended from October 1890 to November 1893. When news of Whitman's death reached her there, she responded with a poem, "The Voiceless Syllables of Grass," whose title blends two of the poet's images. With no attempt to emulate Whitman's style, she offers a simple $a b b a$ stanza to convey her preference for the silent grass as tribute to his memory, rather than Italy's laurel wreaths:

O'er Tuscan hills I heard it breathed,

And up the olive slopes it ran,

And then the laurel all began

Singing of brows once laurel wreathed;

...

Unruffled, silver olives wave,

Loud sings the laurel where I pass,

But louder still I hear the grass

The grass, now growing on a grave. ${ }^{17}$

Hofstra University

JOANN P. KRIEG

\section{NOTES}

1 David S. Reynolds, Walt Whitman's America (New York: Knopf, 1994), 569.

2 Mary A. Hill, Charlotte Perkins Gilman: The Making of a Radical Feminist, 1860-1896 (Philadelphia: Temple University Press, 1980), 155.

3 Florence Bernstein Freedman, William Douglas O'Connor: Walt Whitman's Chosen Knight (Athens, Ohio: Ohio University Press, 1985), 324.

4 Freedman, 255.

5 Freedman, 255.

6 Freedman, 255-257.

7 Hill, 108. For more on the influence of Whitman on Gilman see my "Charlotte Perkins Gilman and the Whitman Connection," Walt Whitman Quarterly Review 1 (March 1984), 21-25, and Denise D. Knight, "'With the First Grass-Blade': Whitman's Influence on the Poetry of Charlotte Perkins Gilman," Walt Whitman Quarterly Review 11 (Summer 1993), 18-29.

8 Mary Armfield Hill, Endure: The Diaries of Charles Walter Stetson (Philadelphia: Temple University Press, 1982), 201. 
9 Hill, Endure, 201-202.

10 Horace Traubel, With Walt Whitman in Camden, 3 vols. (New York: Rowman and Littlefield, 1961), 1:10; Hill, 343.

11 Traubel, 1:10.

12 Traubel, 1:10. Channing may in fact not have found this ghastly; her reaction to Whitman's "The City Dead-House" was to write O'Connor, "Walt has never written anything so divinely beautiful" (Traubel, 1:74).

13 Traubel, 2:115.

14 Traubel, 2:115-116.

15 Traubel, 3:11.

16 Freedman, 325.

17 Grace Channing, Sea-Drift (Boston: Small, Maynard, 1899), 61-62. 